\title{
NUMERICAL ANALYSIS OF LOCAL AND GLOBAL BUCKLING OF A STIFFENED BEAM- COLUMN
}

\author{
Noureddine Toumi, Taško Maneski, Tarek Aburuga, Biserka Nestorovic, Dražan Kozak, Pavel Beno
}

Preliminary communication

The linear buckling phenomenon is obviously very important for stability of compressed supports. The determination of buckling resistance is an important characteristic of the design of steel structure. Besides, the presence of stiffeners in structural plate elements has a vital role in order to increase critical buckling load capacity. However, these stiffeners cause a redistribution in buckling behaviour in terms of local and global buckling. In this paper the transverse and longitudinal stiffeners were employed on a real beam-column structure to maximize the critical buckling loads. The objective is to find the optimum geometry of stiffeners. Based on the finite element method, a numerical model is made using the Abaqus program in order to observe the critical buckling capacity. The results showed that the local critical buckling has been significantly affected by stiffener's position in the case of transverse stiffeners, but little effect is observed on the critical local and global buckling in the case of longitudinal stiffeners.

Keywords: beam-column; finite element method; local and global buckling; transverse and longitudinal stiffener

Numerička analiza lokalnog i globalnog izvijanja ojačane grede

Prethodno pripćenje

Fenomen linearnog izvijanja je očito vrlo bitan za stabilnosti tlačenih nosača. Kritična sila izvijanja predstavlja važnu karakteristiku za projektiranje čeličnih konstrukcija. Osim toga, postojanje ukrućenja na konstrukcijskim elementima ploče ima vitalnu ulogu u cilju povećanja kritične sile izvijanja. Međutim, ova ukrućenja izazvaju preraspodjelu načina izvijanja u smislu lokalnog i globalnog izvijanja. U ovom radu uvedena su poprečna i uzdužna ukrućenja stvarne gredne konstrukcije sa zadatkom da maksimalno povećaju kritične sile izvijanja. Funkcija cilja je pronaći optimalnu geometrijsku karakteristiku ukrućenja. Na osnovu metode konačnih elemenata, numerički model je napravljen uporabom Abakus programa za utvrđivanje kritične sile izvijanja. Rezultati su pokazali da poprečna ukrućenja i njhov položaj imaju znatan utjecaj na lokalno izvijanje, dok uzdužna ukrućenja imaju mali utjecaj na lokalno i globalno izvijanje.

Ključne riječi: greda-stup; lokalno i globalno izvijanje; metoda konačnih elemenata; poprečno i uzdužno ukrućenje

\section{Introduction}

In many industrial applications thin-walled plates and beam-columns are widely used, due to the increasing of demands for structural plate elements, mainly due to their high strength to weight ratio, and stiffness to weight ratio. When the compressive force is applied over entire or a part of cross section, the local or global distortion or mixed modes of buckling may appear. Any of these modes may lead to failure due to excessive deformation of structural members. Therefore, it is highly recommended and important to calculate the critical buckling capacity associated with the various modes to avoid the loss of stability. Recently, finite element analysis (FEA) of structures has played an increasingly significant role in solving engineering problems, as it is time efficient and economical compared with laboratory experiments. Girders, flanges and webs are slender compared with the rest dimensions of a structure, and tend to buckle locally prior to global buckling. In order to prevent buckling and increase buckling load, transverse or longitudinal stiffeners are required. Transverse stiffeners (TS) are primarily added to obtain a higher local buckling capacity under compressive force. On the other hand, longitudinal stiffeners (LS) are meant to perform a similar task in the elastic region. The global-local buckling performance of thin plates in compression can be improved by the provision of longitudinal, transverse stiffener parallel and perpendicular to the direction of the force, respectively. The study of stiffened plates has a long history. Troitsky [1] has discussed the earlier developments in this area. Bryan [2] studied the stability of stiffened plates under uniform compression by applying energy criteria. Timoshenko [3], Timoshenko and Gere [4] presented numerical tables for buckling loads of rectangular plates stiffened by longitudinal and transverse ribs. The stiffened beam-column may fail in two different modes of skin buckling and global buckling, as shown in Fig. 1, where the former one is known as local buckling. The local buckling loads are predicted approximately based on boundary conditions correctly assumed at the edges of column skin and stiffeners, while global buckling loads of stiffened beam-column are usually assessed using the Euler's theory. Due to the lack of a sufficient theoretical solution for more complicated cases such as stiffened beam-column, numerical solutions are often preferred. Sheikh et al. [5] have used finite element method to investigate the stability of stiffened steel plates under uniaxial compression and bending loads.

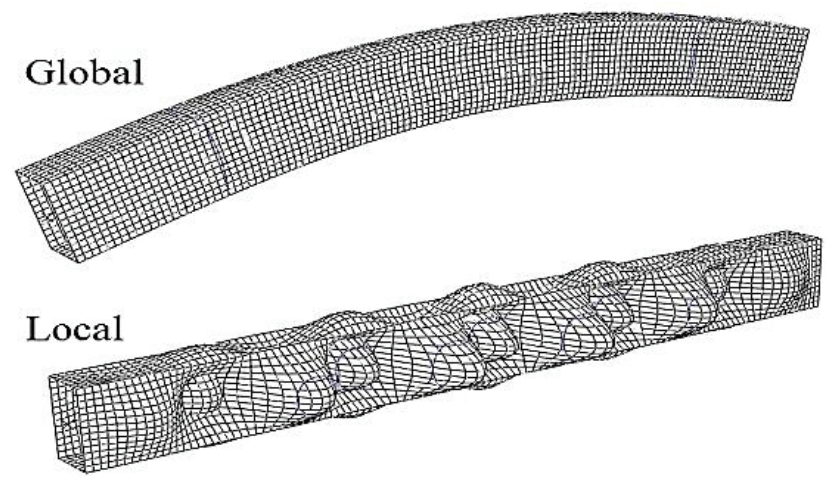

Figure 1 Typical lowest buckling pattern of an isotropic, unstiffened beam-column 
In this paper, the study of local and global buckling modes of transversly and longitudinally stiffened beamcolumn of a real structure under uniaxial load is considered. The horizontal beam-column has been investigated in order to diagnose its buckling behavior under compression force. The main objective of this study is to investigate the geometry (i.e. location and thicknesses) effect of transverse and longitudinal stiffeners on buckling behavior of a structure (e.g. beamcolumn). The finite element models have been made in order to find the optimum position of the stiffener and to avoid any premature failures by using transverse and longitudinal bracing [6] i.e. to gain maximum buckling capacity.

\section{$2 \quad$ Finite element modelling \\ 2.1 General}

In this work, general purpose commercial finite element software Abaqus [7] has been used to determine the load carrying capacity of a beam-column element subjected to pure axial compression by perfoming study on the effects of various parameters, such as thicknesses and distance between stiffeners. The analysis presented in this section involves modelling of both local and global buckling capacity, whereas the FE modelling details are shown in the subsequent sub-sections.

\subsection{Geometric modelling and numerical analysis}

The hollow beam-column has been taken for the analysis with its dimensions illustrated in Fig. 2. The hollow beam-column has length $L=24 \mathrm{~m}$, width $w=1,4$ $\mathrm{m}$, height $h=2,4 \mathrm{~m}$ and thicknesses $t_{1}$ and $t_{2}$ are 0,02 and $0,032 \mathrm{~m}$ respectively. The stiffeners which are used in the analysis are shown in Fig. 3 and Fig. 4 and tied to beamcolumn along the length direction of the column using instance merge which is available in Abaqus [7]. The analysis is done in the following cases:

Case 1: The analysis is made by placing only transverse stiffeners through the column length at different spaces.

Case 2: Next the analysis is done by adding one longitudinal stiffener with transverse stiffeners at the middle of both vertical sides $(h / 2)$ along the column length.

Case 3: Further the analysis is performed by adding two longitudinal stiffeners with transverse stiffeners at one third of both vertical sides $(h / 3)$ along the column length.

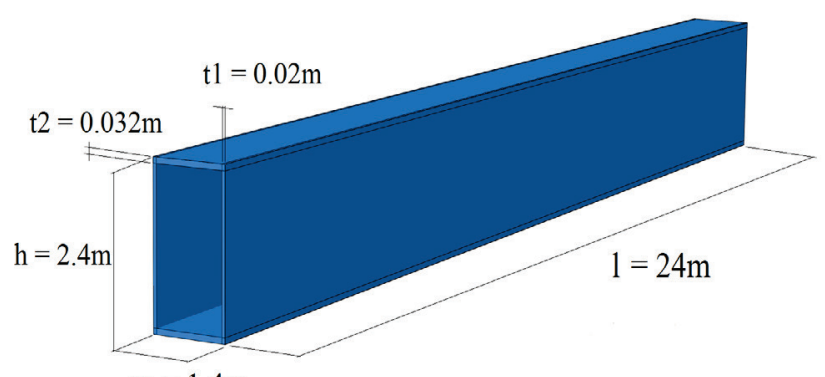

$\mathrm{W}=1.4 \mathrm{~m}$

Figure 2 Typical geometry of a beam-column used in this study

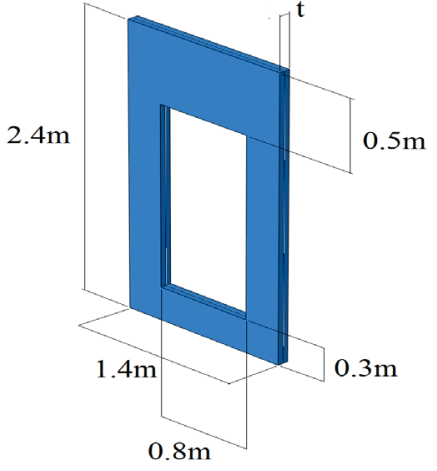

Figure 3 Geometry of transverse stiffener configuration (TS)

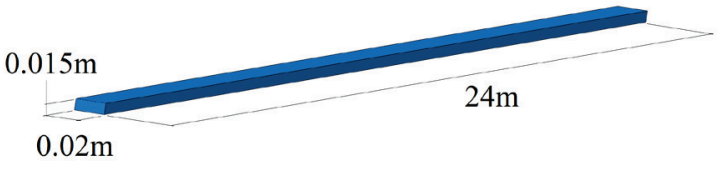

Figure 4 Geometry of longitudinal stiffener configuration (LS)

\subsection{Boundary conditions and finite element mesh}

The beam-column ends are constrained with reference points RP1 and RP2 (Fig. 5) as demanded in Abaqus [7]. The reference points are used to accomplish the boundary conditions to be tied to the end beamcolumn surfaces. The boundary conditions used are given in table 1 and the force is applied statically by a central buckling load of $1 \mathrm{~N}$ at RP1 as shown in Fig. 5. The general purpose elastic shell element is used to discretise the model. Four nodded doubly curved shell elements with reduced integration S4R with six degrees of freedom per node were used [7]. This type of element shows the accurate solution and satisfactory performance in verification work previously described for both thin and thick shell elements [8]. The global size of mesh is kept at 0.1 meter in all finite element models as shown in Fig. 5 with free element shape. The material of the beamcolumn is assumed to be homogeneous, isotropic and elastic with material properties for density $=7850 \mathrm{~kg} / \mathrm{m}^{3}$, Young's modulus $E=200 \mathrm{GPa}$ and Poision's ratio $v=$ 0,3 .

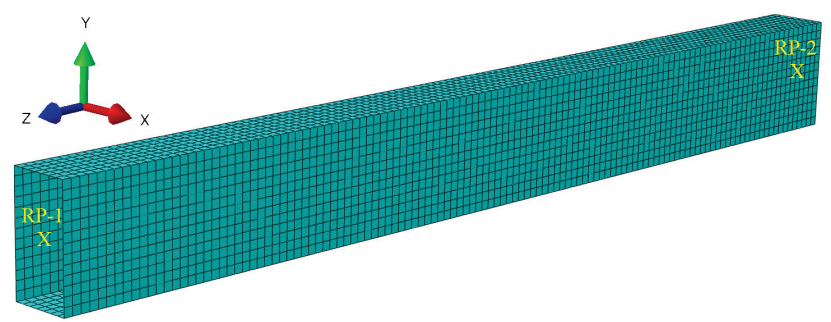

Figure 5 TypicalFE model of a hollow beam-column

Table 1 Boundary conditions of supported model

\begin{tabular}{ccccccc}
\hline & \multicolumn{6}{c}{ Boundary conditions (Free: $\circ$, Constrained: $\bullet$ ) } \\
\cline { 2 - 7 } & $u$ & $v$ & $w$ & $\theta_{x}$, & $\theta_{y}$ & $\theta_{z}$ \\
RP1 & $\bullet$ & $\bullet$ & $\circ$ & $\circ$ & $\bullet$ & $\bullet$ \\
RP2 & $\bullet$ & $\bullet$ & $\bullet$ & $\circ$ & $\bullet$ & $\bullet$ \\
\hline
\end{tabular}

$u, v, \mathrm{w}$ are translations in $x, y, z$ axes.

$\theta_{x}, \theta_{y}, \theta_{z}$ are rotations about $x, y, z$ axes. 


\subsection{Buckling and Finite Element Analysis}

Buckling is well known phenomenon, affecting significantly structural integrity, as described in [9, 10]. From finite element point of view, Campbell et al. and Lee [11] stated that the procedure for buckling analysis of a structure consists of three steps. First, a linear buckling analysis is carried out. The linear buckling analysis is described by Cook et al. [12] as an eigenvalue problem which involves the solution of a homogenous algebraic equation system whose smallest root eigenvalue corresponds to critical buckling load and the associated eigenvector represents the first buckling mode. Using the standard finite element approach, the governing equation for buckling takes the form of the standard eigenvalue problem:

$$
[K]\{D\}=\{R\}_{\text {ref }}
$$

where $[K]$ is the stiffness matrix, $\{D\}$ is the displacement vector and $\{R\}_{\text {ref }}$ is the load. When displacements are known, stresses can be calculated for applied forces, $\{R\}_{\text {ref }}$, which can be used to form the stress stiffness matrix $\left[K_{\sigma}\right]_{\text {ref. }}$. Since the stress stiffness matrix $\left[K_{\sigma}\right]_{\text {ref }}$ is proportional to the load vector $\{R\}_{\text {ref }}$, an arbitrary stress stiffness matrix and an arbitrary load vector $\{R\}$ may be defined by a constant $\lambda$ as

$$
\left[K_{\sigma}\right]=\lambda\left[K_{\sigma}\right]_{\text {ref }} \text { when }\{R\}=\lambda\{R\}_{\text {ref }}
$$

The conventional stiffness matrix $[K]$ is unchanged by the applied load, because the problem is assumed to be linear. When the buckling displacement increment $\{\delta D\}$ takes place relative to displacements $\{D\}_{\text {ref }}$ of the reference configuration because external loads do not change at a bifurcation point.

$$
\begin{aligned}
& \left([K]+\lambda_{\mathrm{cr}}\left[K_{\sigma}\right]_{\mathrm{ref}}\right)\{D\}_{\text {ref }}=\lambda_{\mathrm{cr}}\{R\}_{\text {ref }} \\
& \left([K]+\lambda_{\mathrm{cr}}\left[K_{\sigma}\right]_{\text {ref }}\right)\left(\{D\}_{\text {ref }}+\{\delta D\}\right)=\lambda_{\mathrm{cr}}\{R\}_{\text {ref }}
\end{aligned}
$$

By subtraction of Eq. (3) from Eq. (4), the eigenvalue problem (Eq. (5)) is defined, where the smallest root $\lambda_{\text {cr }}$ defines the smallest load when the bifurcation appears, Eq. (6):

$$
\begin{aligned}
& \left([K]+\lambda\left[K_{\sigma}\right]_{\text {ref }}\right)\{\delta D\}=\{0\} \\
& \{R\}_{\text {cr }}=\lambda_{\text {cr }}\{R\}_{\text {ref }}
\end{aligned}
$$

In order to solve the eigenvalue problem, Abaqus is used, [7]. However, it is always possible and sometimes desirable to create a faster eigenvalue solver that is designed for the specific case to be solved. Lanczos method, [13], is generally faster when a large number of eigen modes is required for a system with many degrees of freedom while the Subspace method, [14], is faster when only a few (less than 20) eigen modes are needed. The second step of the analysis is nonlinear buckling analysis in which large deformations and geometrical and/or material non-linearities are included. This type of analysis may include some imperfections after a linear buckling analysis. Post buckling analysis is the third step that may be carried out for investigating if the structure continues to carry the load after it has reached its critical limit or if it loses all its stiffness and collapses. In this study only a linear buckling analysis is considered, because the analysis is done for "stiff" structures, so it was not necessary to include the effect of geometry change in establishing the equilibrium for the base state.

\section{Parametric studies of stiffened column}

The effect of two types of stiffeners has been adopted in this study as the key parameters in terms of thickness and locations. To investigate the effects of these parameters on critical buckling load, three cases of stiffened beam-columns were considered under pure axial compression as mentioned before in section 2.2. The considered sections are shown in Fig. $6 \div 9$ in the parametric study of these beam-columns. The parametric study was analyzed for transverse stiffeners thicknesses varying from $15 \mathrm{~mm}$ to $30 \mathrm{~mm}$, while the longitudinal stiffeners thicknesses were kept at only $15 \mathrm{~mm}$.

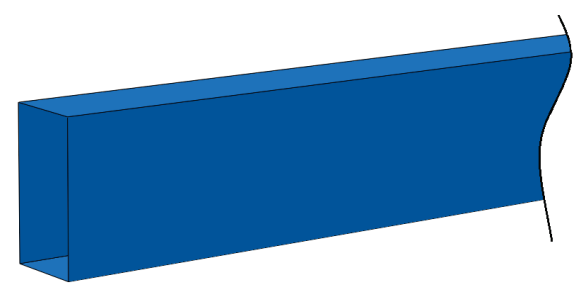

Figure 6 Specimen section of a hollow beam-column

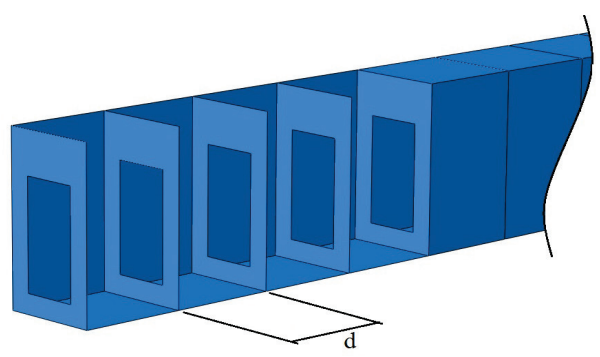

Figure 7 Specimen section of a beam-column using only TS - TS distance variation $(d)=0,5 ; 1,0 ; 1,5 ; 2,0 ; 2,5 ; 3,0 \mathrm{~m}$

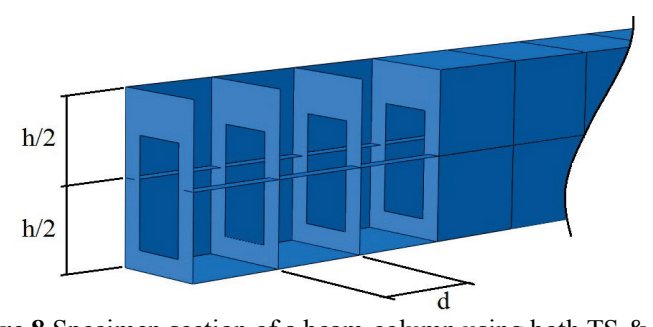

Figure 8 Specimen section of a beam-column using both TS \& two of LS - TS distance variation $(d)=0,5 ; 1,0 ; 1,5 ; 2,0 ; 2,5 ; 3,0 \mathrm{~m}$ and LS distance $(h / 2)=1,2 \mathrm{~m}$

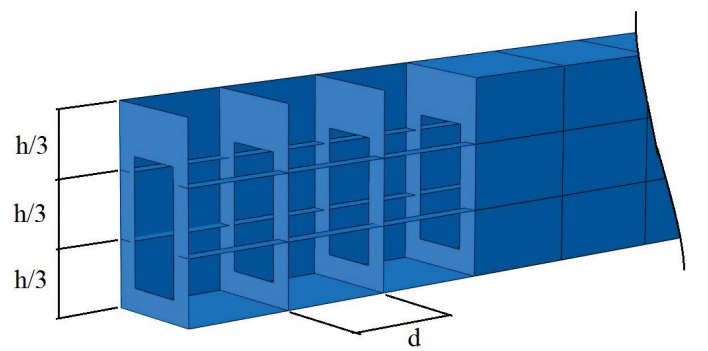

Figure 9 Specimen section of a beam-column using both TS \& four of LS - TS distance variation $(d)=0,5 ; 1,0 ; 1,5 ; 2,0 ; 2,5 ; 3,0 \mathrm{~m}$ and LS distance $(h / 3)=0,8 \mathrm{~m}$ 


\section{Results and Discussions}

The first eigen buckling modes on deformed shapes at critical local and global buckling loads for some samples are shown in Figs. $10 \div 12$. Obviously, the onset of buckling modes can be seen along with distribution of magnitude deformation over the surfaces. The study started by adding only TS inside the beam-column, and then two models of stiffened beam-columns have been analyzed by adding both TS \& LS stiffeners at various locations. The variable values of stiffener distances and critical buckling load are investigated and plotted for different thicknesses and the obtained results summarized as follows.

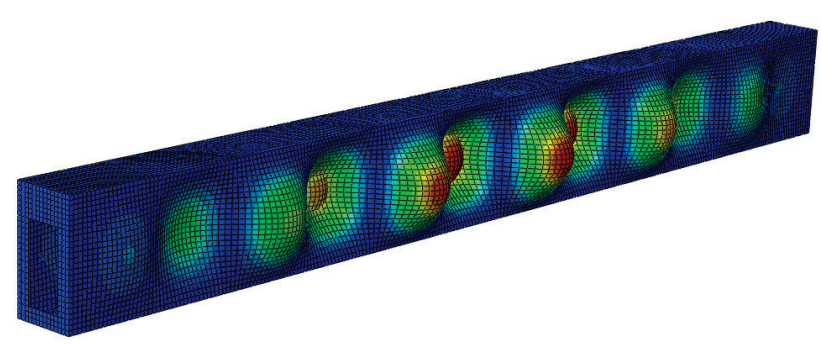

$P_{\mathrm{cr}}=1,37 \times 10^{7} \mathrm{~N}$ (local buckling). TS distance $(d)=2 \mathrm{~m}$. TS thickness $(t)=0,015 \mathrm{~m}$

Figure 10 Samples of first eigen buckling modes of column using TS only

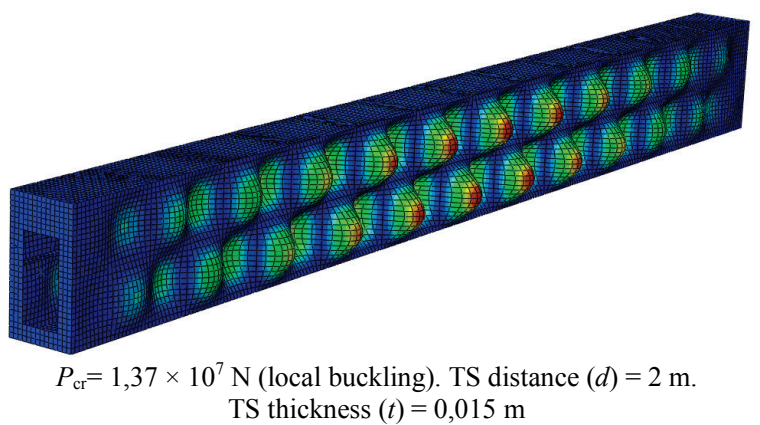

Figure 11 Samples of first eigen buckling modes of column using TS \& two LS

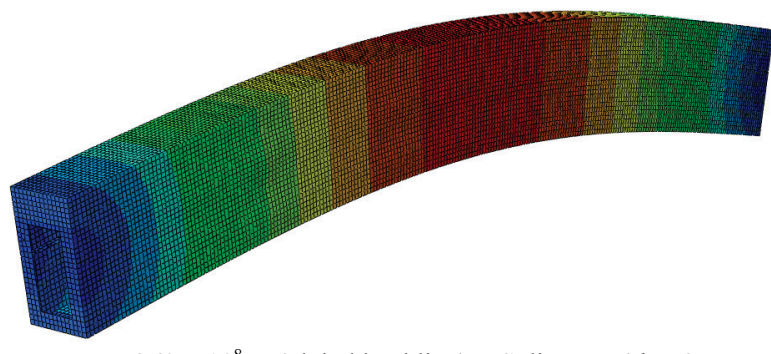

$P_{\mathrm{cr}}=6,60 \times 10^{8} \mathrm{~N}$ (global buckling). TS distance $(d)=2 \mathrm{~m}$. TS thickness $(t)=0,015 \mathrm{~m}$

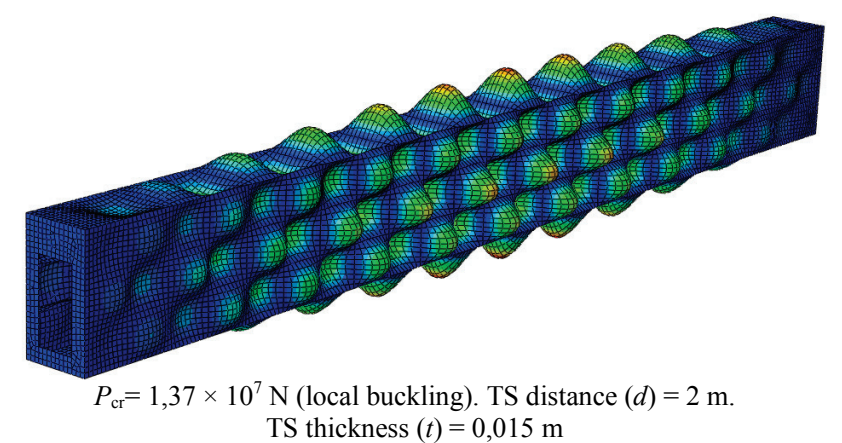

Figure 12 Samples of first eigen buckling modes of column using TS \& four LS

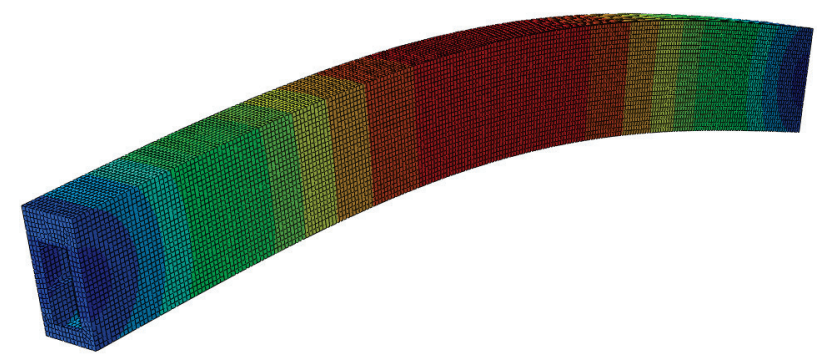

$P_{\text {cr }}=6,60 \times 10^{8} \mathrm{~N}$ (global buckling). TS distance $(d)=2 \mathrm{~m}$.

TS thickness $(t)=0,015 \mathrm{~m}$

(ii) For the case involving TS through the beam-column length and using two LS which are arranged at the middle of both vertical sides $(h / 2)$, results indicate that the significant improvements are obtained in local buckling loads, as shown in Fig. 15. The improvements are $39 \%$ the minimum and $64 \%$ the maximum at 0,5 and $2 \mathrm{~m}$, respectively. Consequently, local buckling loads are very sensitive to longitudinal stiffeners, although they are placed to support transverse stiffeners. However, it can be observed from Fig. 16 that the improvements in global buckling loads have a similar trend as in case 1 .

(iii) For the case involving TS through the beam-column length and using four LS arranged at one third of both vertical sides, the effect of longitudinal stiffeners on both local and global buckling is shown clearly in Fig. 17 and Fig. 18. The best improvement is obtained by $50 \%$ at $0,5 \mathrm{~m}$ distance specially in local buckling loads, compared with previous cases. It can be observed from Fig. 14 that local buckling occurs 
between TS and LS in a mode similar to the buckling mode of an infinity plate with simply supported edges. It can be seen from these two diagrams that there is minor changing, which becomes practically negligible in both local and global critical buckling after 2 meters distance between TS. The reason is that the compression loads are redistributed between the stiffeners and the beam-column's skin, according to their stiffness ratio, where the global stiffness of the stiffened beam-column decreased when the local buckling occurred in its skin.

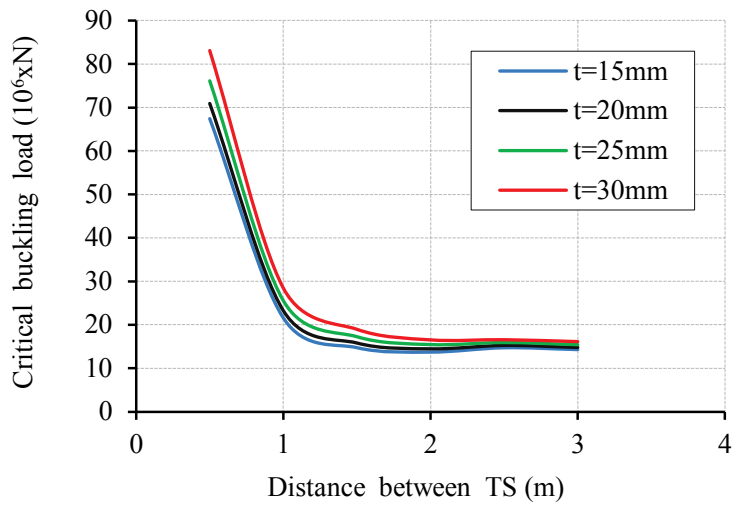

Figure 13 Effect of TS on critical local buckling of the beam-column (case 1)

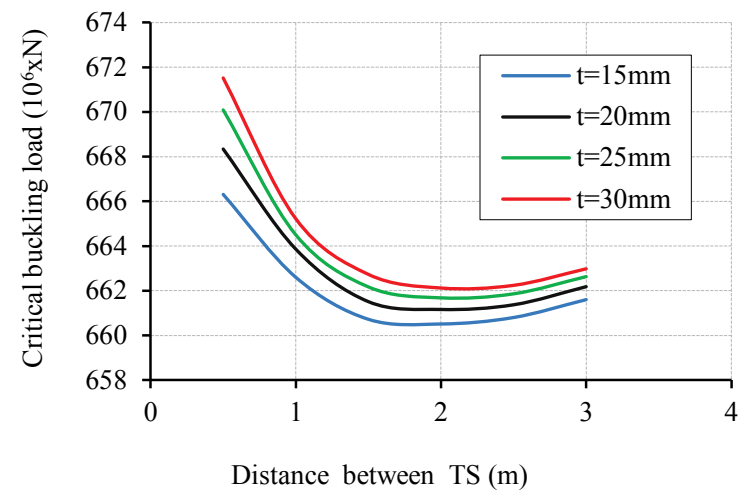

Figure 14 Effect of TS on critical global buckling of the beam-column (case 1)

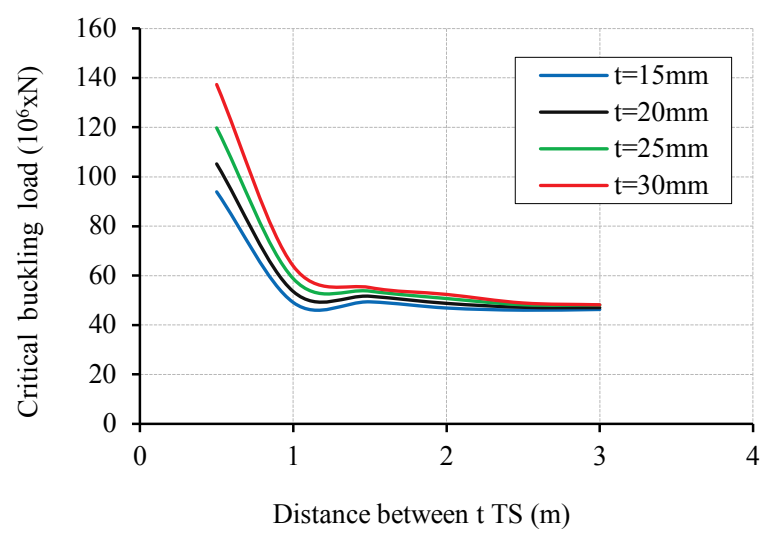

Figure 15 Effect of TS \& two LS on local, global buckling of the beamcolumn (case 2)

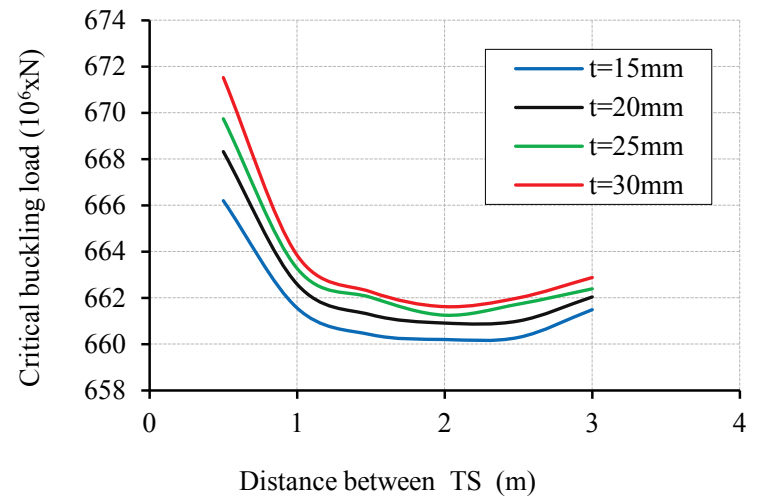

Figure 16 Effect of TS \& two LS on critical global buckling of the beam-column (case 2)

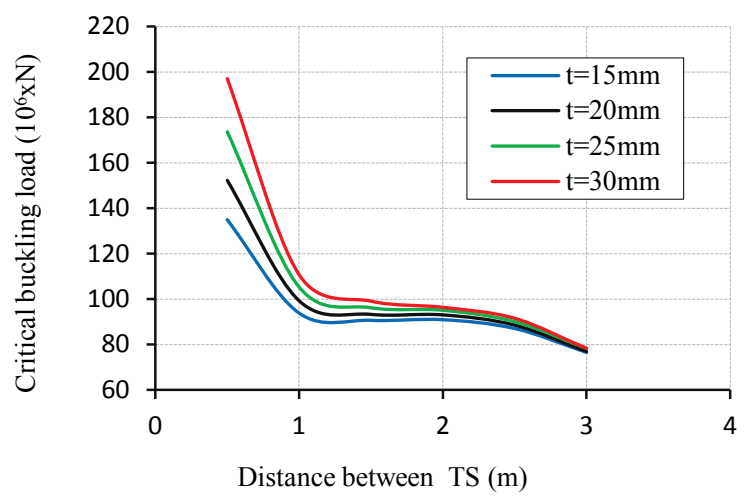

Figure 17 Effect of TS \& four LS on critical local buckling of the beam-column (case 3)

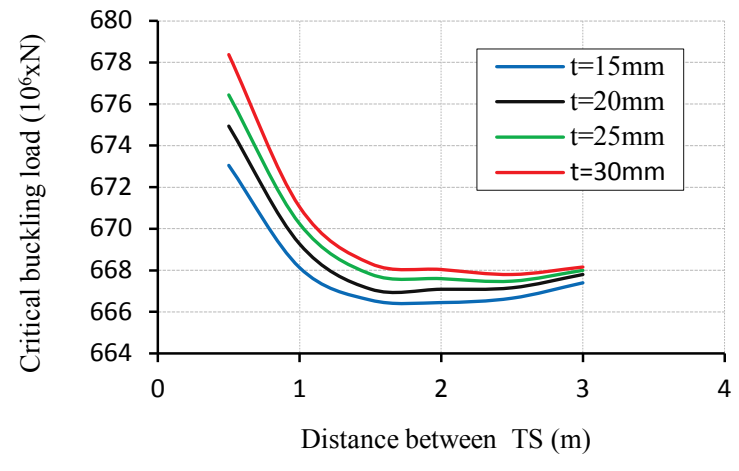

Figure 18 Effect of TS \& four LS on critical global buckling of the beam-column (case 3)

\section{Conclusion}

In order to investigate the critical buckling load, local and global buckling pattern of beam-column under the uniaxial compression load, the stiffened beam-columns in three configurations with two different stiffeners were designed and tested. The effects of the transverse and longitudinal stiffeners on the critical buckling capacity of the stiffened beam - column were analyzed based on finite element results. The buckling capacity of stiffened beamcolumns demonstrated the ability to observe accurately where is the optimum position and thickness of stiffeners. The conclusions were drawn as the following:

a) For all the beam-columns' configurations considered, a sharp decrease in critical buckling loads with distance between TS up to 1,5 meter has been 
observed, although the increase in distance between TS was relatively slower.

b) A nearly linear decrease in critical buckling loads has been noticed, as the distance between TS is changed from 2 to 3 meters.

c) Investigation of various models shows that the transverse stiffener thickness has an effect on critical buckling load in particular for a short distance between transverse stiffeners.

d) The substantial improvement in critical buckling load due to the use of stiffeners occurs when TS and LS stiffeners are applied together.

e) The maximum spacing between transverse stiffeners should not exceed 2 meters to be efficient.

\section{Acknowledgements}

The first author is thankful to Prof. Taško Maneski for the support, valuable discussions and comments. The authors are very much indebted to Dr. Tarek Aburuga for fruitful discussions and suggestions.

\section{References}

[1] Troitsky, M. S. Stiffened Plates, Buckling, Stability and Vibration. Elsevier Scientific Publishing Co., Amsterdam, (1976).

[2] Bryan, G. H. On the stability of a plane plate under thrust in its own plane, with applications to the buckling of the sides of a ship. // Proc. Land. Math. Sot. . 22, 1(1891), pp. 54-67.

[3] Timoshenko, S. P. On the stability of the stiffened plates. Der Eisenbau. 12, 2(1936), pp. 147-163.

[4] Timoshenko, S. P.; Gere, J. M. Theory of Elastic Stability. McGraw-Hill book Inc., New York, 1961.

[5] Sheikh, I. A.; Grodin, G.Y.; Elwi, A., E. Stiffened steel plates under uniaxial compression. // Journal of Constructional Steel Research. 58, 5-8(2002), p.p 1061-1080. https://doi.org/10.1016/S0143-974X(01)00083-9

[6] Čaušević M.; Bulic, M. Steel plate elements loaded in their plane-buckling factors and critical stresses. // Tehnicki vjesnik - Technical Gazette. 64, 2(2012), pp. 113-123.

[7] Abaqus/Standard user's manual volumes I-III and ABAQUS CAE manual. Version 6.14-EF1, Dassault Systemes Corp., Providence, USA, 2010.

[8] El-Sawy, K. M., Nazmy, A. S. Effect of aspect ratio on the elastic buckling of uniaxially loaded plates with eccentric holes. // Thin-Walled Structures. 39, 12(2001), pp. 983-998. https://doi.org/10.1016/S0263-8231(01)00040-4

[9] Maneski, T.; Danicic, D., Structural performance diagnostics. // Structural Integrity and Life 4, 1(2004), pp. 3-7.

[10] Ćosić, M.; Folić, B.; Sedmak, S. Buckling Analysis of 3D Model of Slender Pile in Interaction with Soil Using Finite Element Method. // Structural Integrity and Life. 12, 3(2012), pp. 221-232.

[11] Campbell, G.; Ting, W.; Aghssa, P.; Hoff, C. C. Buckling and Geometric Nonlinear Analysis of a Tie Rod in MSC Nastran Version 68. // Worlds Users Conference / Arlington, 1994, pp. 1-15.

[12] Cook, R. D.; Malkus D. S.; Plesha M. E.; Witt R. J. Concepts and Applications of Finite Element Analysis. $4^{\text {th }}$ ed. John Wiley \& Sons, 2002.

[13] Bertollini, A. F. Review of Eigensolution Procedures for Linear Dynamic Finite Element Analysis. // Applied Mechanics Reviews. 51, 2(1998), pp. 155-172. https://doi.org/10.1115/1.3098994

[14] Bathe, K. The Subspace Iteration Method Revisited. // Computers and Structures. 126, 15(2013), pp. 177-183. https://doi.org/10.1016/j.compstruc.2012.06.002

\section{Authors' addresses}

Noureddine Toumi, PhD student

University of Belgrade

Faculty of Mechanical Engineering

Kraljice Marije 16

11120 Belgrade 35, Serbia

E-mail: toumi_71@yahoo.com

Prof. dr. Taško Maneski

University of Belgrade

Faculty of Mechanical Engineering

Kraljice Marije 16

11120 Belgrade 35, Serbia

E-mail: tmaneski@mas.bg.ac.rs

Dr. Tarek Aburuga

University of Tripoli

Department of Mechanical Engineering

Tripoli, Libya

E-mail: tareq306@yahoo.com

Prof. dr. Biserka Nestorovic

University of Belgrade

Faculty of Forestry

Kneza Višeslava 1

11000 Belgrade 35, Serbia

E-mail: biserka.nestorovic@sfb.bg.ac.rs

Prof. dr. sc. Dražan Kozak

Josip Juraj Strossmayer University of Osijek

Mechanical Engineering Faculty in Slavonski Brod

Trg Ivane Brlić-Mažuranić 2

35000 Slavonski Brod, Croatia

E-mail: dkozak@sfsb.hr

Prof. Pavel Beno, PhD

Department of Mechanics, Mechanical Engineering and Design, Faculty of Environmental and Manufacturing Technology,

Technical University in Zvolen, Slovak Republic

E-mail: pavel.beno@tuzvo.sk 